\title{
The Sweet Home rhodochrosite specimen mine, Alma District, Central Colorado: the porphyry molybdenum-fluorine connection
}

Paul J. Bartos • Eric P. Nelson • Dean Misantoni

Published online: 22 December 2006

(C) Springer-Verlag 2006

Unfortunately, in the original version of the article, the caption for Fig. 2 is in error in that some of the mines listed within it were misnumbered. The correct list can be found below:

1. Moose Mine, 2. Russia Mine, 3. Dolly Varden Mine, 4. Paris Mine, 5. Phillips Mine, 6. Orphan Boy Mine, 7. Hock Hocking Mine, 8. South London Mine, 9. North London Mine, 10. Sweet Home Mine, 11. Kite Lake Prospect, 12. Climax Mine, 13. Continental Chief (Mt. Sherman) Mine, 14. John Reed Mine, 15. Alma Placer.

The online version of the original article can be found at: http://dx.doi. org/10.1007/s00126-006-0103-5.

P. J. Bartos $(\bowtie) \cdot$ E. P. Nelson

Department of Geology and Geological Engineering,

Colorado School of Mines,

1516 Illinois Street,

Golden, CO 80401, USA

e-mail: pbartos@mines.edu

D. Misantoni

Colorado Calumet Company Inc.,

P.O. Box 1169, Golden, CO 80402, USA 